\title{
Targeting Certain Interleukins as Novel Treatment Options for Liver Fibrosis
}

\section{OPEN ACCESS}

Edited by: Ralf Weiskirchen,

RWTH Aachen University, Germany

Reviewed by:

Steven O'Reilly,

Durham University, United Kingdom Wei Chen,

Stanford University, United States

${ }^{*}$ Correspondence: Sharon DeMorrow sharon.demorrow@ austin.utexas.edu

Specialty section: This article was submitted to Gastrointestinal and Hepatic Pharmacology, a section of the journal Frontiers in Pharmacology

Received: 23 December 2020 Accepted: 16 February 2021 Published: 24 March 2021

Citation: An SY, Petrescu AD and DeMorrow S (2021) Targeting Certain Interleukins as Novel Treatment Options for Liver Fibrosis. Front. Pharmacol. 12:645703. doi: 10.3389/fphar.2021.645703

\author{
Su Yeon $A n^{1}$, Anca D. Petrescu ${ }^{1}$ and Sharon DeMorrow ${ }^{1,2,3 *}$ \\ ${ }^{1}$ Division of Pharmacology and Toxicology, College of Pharmacy, The University of Texas at Austin, Austin, TX, United States, \\ ${ }^{2}$ Department of Internal Medicine, Dell Medical School, The University of Texas at Austin, Austin, TX, United States, ${ }^{3}$ Research \\ Division, Central Texas Veterans Healthcare System, Temple, TX, United States
}

The liver is a major metabolic organ and an immunologically complex organ. It produces and uses many substances such as acute phase proteins, cytokines, chemokines, and complementary components to maintain the balance between immunity and tolerance. Interleukins are important immune control cytokines, that are produced by many body cells. In liver injury, interleukins are produced in large amount by various cell types, and act as pro-inflammatory (e.g. interleukin (IL)-6, IL-13, IL-17, and IL-33) as well as antiinflammatory (e.g. IL-10) functions in hepatic cells. Recently, interleukins are regarded as interesting therapeutic targets for the treatment of liver fibrosis patients. Hepatic cells such as hepatocytes, hepatic stellate cells, and hepatic macrophages are involved to the initiation, perpetuation, and resolution of fibrosis. The understanding of the role of interleukins in such cells provides opportunity for the development of therapeutic target drugs. This paper aims to understand the functional roles of interleukins in hepatic and immune cells when the liver is damaged, and suggests the possibility of interleukins as a new treatment target in liver fibrosis.

Keywords: interleukins, hepatocytes, macrophages, hepatic stellate cells, CD4 ${ }^{+} \mathbf{T}$ helper cells, liver fibrosis

\section{INTRODUCTION}

Fibrosis is the pathological feature and the end result of chronic inflammatory reaction induced by various types of injuries in several organs including skin, kidney, lung, heart, intestine, and liver. Therefore chronic fibroproliferative diseases is a major public health problem (Nanchahal and Hinz, 2016). In the liver, progressive fibrosis caused by injury, inflammation, and extracellular matrix (ECM) accumulation ultimately results in cirrhosis or hepatocellular carcinoma. The only effective treatment for these terminal liver disorders is liver transplantation (Bataller and Brenner, 2005; Bansal et al., 2016). For this reason, treatment at the liver fibrosis stage that prevents the progression of the disease, and that leads to resolution is very important.

\footnotetext{
Abbreviations: $\alpha$-SMA, $\alpha$-smooth muscle actin; CCl4, Carbon tetrachloride; CD4 T cells; CD4+ T helper cells; DAMP, Danger associated molecular patterns; ECM, Extracellular matrix; ERK, Extracellular signal regulated kinase; HSCs, Hepatic stellate cells; IL, Interleukin; IL-10R, IL-10 receptor; ILC2, Innate lymphoid cells; JAK, Janus kinase; MAPK; Mitogen-activated protein kinase; MCs, Mast cells; MoMFs, Monocytes-derived macrophages; MyD88, Myeloid differentiation primary response gene 88; NF-kB; Nuclear factor- $\mathrm{kB}$, PDGF, Platelet-derived growth factor; STAT, Signal transducer and activator of transcription; TGF- $\beta$, Transforming growth factor- $\beta$; Th, T helper; TRAF6, Tumor necrosis factor receptor-associated factor 6 ; Tregs, Regulatory T cells; TYK, Tyrosine kinase.
} 
The initiation, perpetuation and resolution of liver fibrosis is a complex process of communication between cells receiving a multitude of signals consisting of various growth factors, chemokines and cytokines (Kubes and Jenne, 2018). Interleukins, a cytokine family that include chemokines, interferons, lymphokines, and tumor necrosis factors, were first thought to be expressed in leukocytes alone, but it was later found that about 40 types of interleukins were produced by many other body cells. Interleukins play an essential role in the activation and differentiation of immune cells as well as proliferation, maturity, migration, and adhesion. They can also have pro-inflammatory or anti-inflammatory or both properties (Hammerich and Tacke, 2014).

IL-6 and IL-1 are representative keystone cytokines in liver disease and have both pro and anti-inflammatory properties. IL-6 is a main regulatory factor in processes of wound healing and tissue regeneration related to various liver injures. It was concluded that IL-6/STAT3 signaling prevents cholestasis and liver fibrosis and has role in regulation of hepatocyte and cholangiocyte functions in the model of sclerosing cholangitis (Mair et al., 2010). However, more recent publications reveal negative effects of IL-6 which can directly induce transition of HSCs to myofibroblast-like cells, in hepatic fibrosis (Kagan et al., 2017). Very recent studies on the role of JAK-STAT signaling in hepatocellular carcinoma (HCC) emphasized that members of IL-6 family of cytokines have emerged as important regulatory factors and are considered to be targets for therapeutic intervention (Lokau et al., 2019). IL-1 family consists of 11 cytokines of the innate immune system. These cytokines trigger various immune responses to liver injuries, i.e. IL-1 $\alpha, \beta$ and IL-33 are proinflammatory cytokines; in contrast, IL-1Ra, IL36Ra, IL-37, and IL-38 have anti-inflammatory responses, while IL-18 was found to be pro- and anti-inflammatory under different circumstances (Barbier et al., 2019; Chan and Schroder, 2020). Additionally, IL-1 cytokines activate mast cells (MCs) to secrete inflammatory mediators (chemokines and cytokines including IL-1, IL-33 and TNF), and this effect can be counteracted by IL-37 (Gallenga et al., 2019). Thus, it has been determined that IL-37 is an anti-inflammatory cytokine that interacts with IL-18Ra chain and decreases the inflammatory effects of IL-1 cytokines (Toniato et al., 2017; Caraffa et al., 2019; Gugliandolo et al., 2019). Cytokines from IL-36 subfamily of IL-1 are produced by activated MCs and have strong pro-inflammatory effects which can be balanced by IL-38 which binds to IL-36R inducing anti-inflammatory activity (Varvara et al., 2018; Gallenga et al., 2019). Numerous studies have investigated the role of each cytokine and receptor from this family in various types of liver injuries, and have been reviewed in detail recently (He et al., 2021).

This review presents and emphasizes certain interleukins as potential therapeutic targets for liver fibrosis. We specifically focused on the pro-inflammatory interleukins: interleukin (IL)13, IL-17, and IL-33, anti-inflammatory interleukin: IL-10 based on the numerous studies published in recent years that clearly showed their functions and effects. Furthermore, this review summarizes the origin, function, and signal pathway of these selected interleukins and, also shows the functions of these specific interleukins in hepatocytes, hepatic stellate cells (HSCs), and hepatic macrophages which are main players in liver fibrosis.

\section{CD4 $^{+}$T HELPER CELLS}

The innate and adaptive immune responses occurring simultaneously or sequentially in time, are initiated by Kupffer cells that recognize liver damage. Following liver injury, inflammatory lymphocytes infiltrate the damaged hepatic parenchyma (Dong et al., 2019; Li et al., 2019). T lymphocytes, which are activated through antigen-specific manner of dendritic cells, help the B lymphocytes to create antigen-specific antibodies, or to remove infected cells. Specially, CD4 ${ }^{+} \mathrm{T}$ helper cells (CD4 T cells) serve as the total commander of immunity. CD4 $\mathrm{T}$ cells can be classified into at least four subsets, referred to as $\mathrm{T}$ helper (Th) cells type 1, Th2, Th17, and induced regulatory T cells (Tregs). These cells play a major role in mediating immune response through the secretion of specific cytokines (Luckheeram et al., 2012).

Th1 cells play a particularly important role in mediating immune responses against intracellular pathogens, resistance to mycobacterial infections, and induction of some autoimmune diseases. Their principal cytokine products are interferon gamma, lymphotoxin $a$, and IL-2 (Paul and Seder, 1994). Th2 cells mediate immune response to extracellular parasites, including helminths, and play an important role in induction and persistence of asthma and other allergic diseases. Th2 cells produce IL-4, IL-5, IL-9, IL-13, IL-10, IL-25, and amphiregulin (Luckheeram et al., 2012). Th17 cells are responsible for mediating immune responses against extracellular fungi and bacteria, and for inducing the many organ-specific autoimmune diseases. Th17 cells produce IL-17, IL-17f, IL-21, and IL-22 (Zhu and Paul, 2008). IL-17 leads to the induction of pro-inflammatory cytokines, including IL-6, IL-1, tumor necrosis factor- $\alpha$ (TNF- $\alpha$ ), and thus has an important role in inducing inflammatory responses (Luckheeram et al., 2012). Tregs play a critical role in the maintenance of self-tolerance to self and foreign antigen. Increasing Tregs numbers and/or enhancing their suppressive function may be beneficial for preventing allograft rejection and treating autoimmune diseases. The main effector cytokines of Tregs include IL-10, transforming growth factor- $\beta$ (TGF- $\beta$ ), and IL-35 (Zhu and Paul, 2008; Luckheeram et al., 2012).

CD4 $\mathrm{T}$ cells release a wide range of inflammatory intermediates, particularly interleukins, which can act as the pro-inflammatory, anti-inflammatory, or two functions in liver fibrosis (Hammerich and Tacke, 2014; Sziksz et al., 2020). However, selecting interleukins with conflicting functions depending on the stage of liver disease as a therapeutic target requires more attention in the treatment process. In the case of IL-6 or IL-22, it prevents fibrogenesis but promotes hepatocellular carcinoma, so the risk of tumor occurrence should be considered in the treatment of patients with hepatic fibrosis (Schmidt-Arras and Rose-John, 2016; Wu et al., 2020). Therefore, it is very important to select and study targets capable 
of blocking pro-inflammatory (IL-13, IL-17, and IL-33) or inducing anti-inflammatory interleukin (IL-10) in the complex process of liver fibrosis.

\section{TARGET INTERLEUKINS}

\section{Interleukin-10}

IL-10, one of the major anti-inflammatory cytokines, controls neutrophil infiltration and suppresses various pro-inflammatory mediators (Louis et al., 1998; Sziksz et al., 2020). IL-10 can be produced by Th 2 cells but also by Th1, Th17, Tregs, $\mathrm{CD} 8^{+} \mathrm{T}$, and B lymphocytes. In the liver, IL-10 is expressed in various cell types, including hepatocytes, Kupffer cells, sinusoidal endothelial cells, HSCs, and lymphocytes (Hammerich and Tacke, 2014; Sziksz et al., 2020). Functional IL-10 receptor (IL-10R) complexes are tetramers consisting of two IL-10R1 and two IL-10R2 chains. IL-10 homodimer binding to its receptor activate Janus kinase (JAK) 1 and Tyrosine kinase (TYK) 2. Signal transducer and activator of transcription (STAT) 3 binds to IL-10R1 and phosphorylates, and then phosphorylated STAT3 translocate to the nucleus (Figure 1) (Verma et al., 2016).

\section{Interleukin-13}

IL-13 is an immunoregulatory cytokine secreted by predominantly Th2 cells. IL-13 has multiple effects on the differentiation and function of monocytes and macrophages. Although IL-13 plays an important role in the induction of allergic responses and inflammation as anti-inflammatory cytokine, it is a critical pro-fibrotic factor in liver fibrosis associated with Schistosoma and non-Schistosoma infection (De Vries, 1998; Liu et al., 2012). Additionally, IL-13 has been implicated in inflammatory bowel disease, asthma, and parasitic nematode expulsion (Grunig et al., 1998; Hershey, 2003). IL-13 induces many of the same responses and functional properties as IL-4 and shares a receptor subunit, the a subunit of the IL-4 receptor. IL-13 binds to the complex receptor system comprised of IL-4 receptor and two IL-13 binding proteins, IL-13Ra1 and IL-13Ra2. Signaling through the type II receptor (IL-4 receptor and IL13Ra1) leads to activation of JAK1 or JAK2/TYK2, STAT6, STAT3, and STAT1. Then, STAT dimerization and nuclear translocation occurs, followed by activation of gene transcription (Figure 1) (McCormick and Heller, 2015). IL-13 receptor is expressed on human B cells, basophils, eosinophils, mast cells, endothelial cells, fibroblasts, monocytes, macrophages, respiratory epithelial cells, and smooth muscle cells (Hershey, 2003).

\section{Interleukin-17}

IL-17 (now IL-17A) is an ancient pro-inflammatory cytokine with important roles in defense against bacteria and fungi. IL-17 are produced primarily by a T-cell subset termed Th17 cells, but can also be produced by neutrophils and other lymphocytes (Onishi and Gaffen, 2010). IL-17 signals through the IL-17RARC complex, and the IL-17 receptor recruits Act1 for downstream signaling. The Act1 with the IL-17 receptor complex contributes to the recruitment of Tumor necrosis factor receptor associated factor 6 (TRAF6). Then, these kinases promote the production of pro-inflammatory cytokines, chemokines, and-microbial peptides, through the pathway such as nuclear factor- $\mathrm{kB}$ (NF$\kappa \mathrm{B})$, activator protein, and CCAAT/enhancer binding protein pathways (Figure 1) (Onishi and Gaffen, 2010; Meng et al., 2012).

\section{Interleukin-33}

IL-33 is the most recently identified member of IL-1 family of cytokines and is mainly expressed by stromal cells. IL-33 has been shown to induce the Th2 phenotype in Th cell, and therefore promotes progression of Th2-related diseases like several acute and chronic inflammatory diseases, including asthma, atopic dermatitis, rheumatoid arthritis, and ulcerative colitis among others (Schmitz et al., 2005; Sanada et al., 2007). The activity of IL-33 is mediated by binding to the heterodimeric ST2/IL-1 receptor associated protein receptor. Afterward, the complex recruits intracellular signaling molecules, including myeloid differentiation primary response 88 (MyD88)/IL-1 receptor-associated kinase/TRAF6, activating NF- $\kappa \mathrm{B}$, as well as extracellular signal regulated kinase (ERK) 1/2, c-Jun N-terminal kinase, p38 and phosphatidylinositol 3-kinase/protein kinase B (Figure 1) (Pinto et al., 2018; Barbier et al., 2019). Recently, IL-33 has gained attention as a new target or as an early alarm of liver fibrogenesis, as Th2 cells are strongly associated with fibrosis progression (Hammerich and Tacke, 2014; Weiskirchen and Tacke, 2016).

\section{CONTRIBUTION OF THESE TARGET INTERLEUKINS IN THE HEPATIC CELLS}

\section{Interleukins in Hepatocytes}

Hepatocytes are the major parenchymal cells that are important for liver function in metabolism, detoxification, and alcohol processing, and protein synthesis. Hepatocytes also activate innate and adaptive immunity when they are damaged by hepatotropic virus, an intracellular bacterium, or repeated or continuous injury (Crispe, 2016; Zhou et al., 2016). The initial reaction of hepatocytes injury by multiple factors is cell stress and cell death. The stressed and dying hepatocytes release damageassociated molecular patterns (DAMPs), reactive oxygen species, pro-inflammatory signals, and proliferation-associated cytokines through cross-talk with surrounding cells such as HSCs, endothelial cells, and immune cells (Tu et al., 2015; Yan et al., 2018). The reaction of hepatocytes indicate that hepatocytes contribute to the progress and resolution of liver fibrosis as active participants, not victims or bystanders (Tu et al., 2015).

McHedlidze et al. showed that damaged hepatocytes secreted IL-33 and that extracellular IL-33 leads to accumulation and activation of innate lymphoid cells (ILC2) (McHedlidze et al., 2013). Activated ILC2 by IL-33 produce IL-13, which induced the activation and trans-differentiation of HSCs through type-II IL-4 receptor-dependent signaling and STAT6. Further studies have identified IL-33 as key mediator of hepatic fibrosis by demonstrating that IL-33 deficiency ameliorates liver fibrosis 


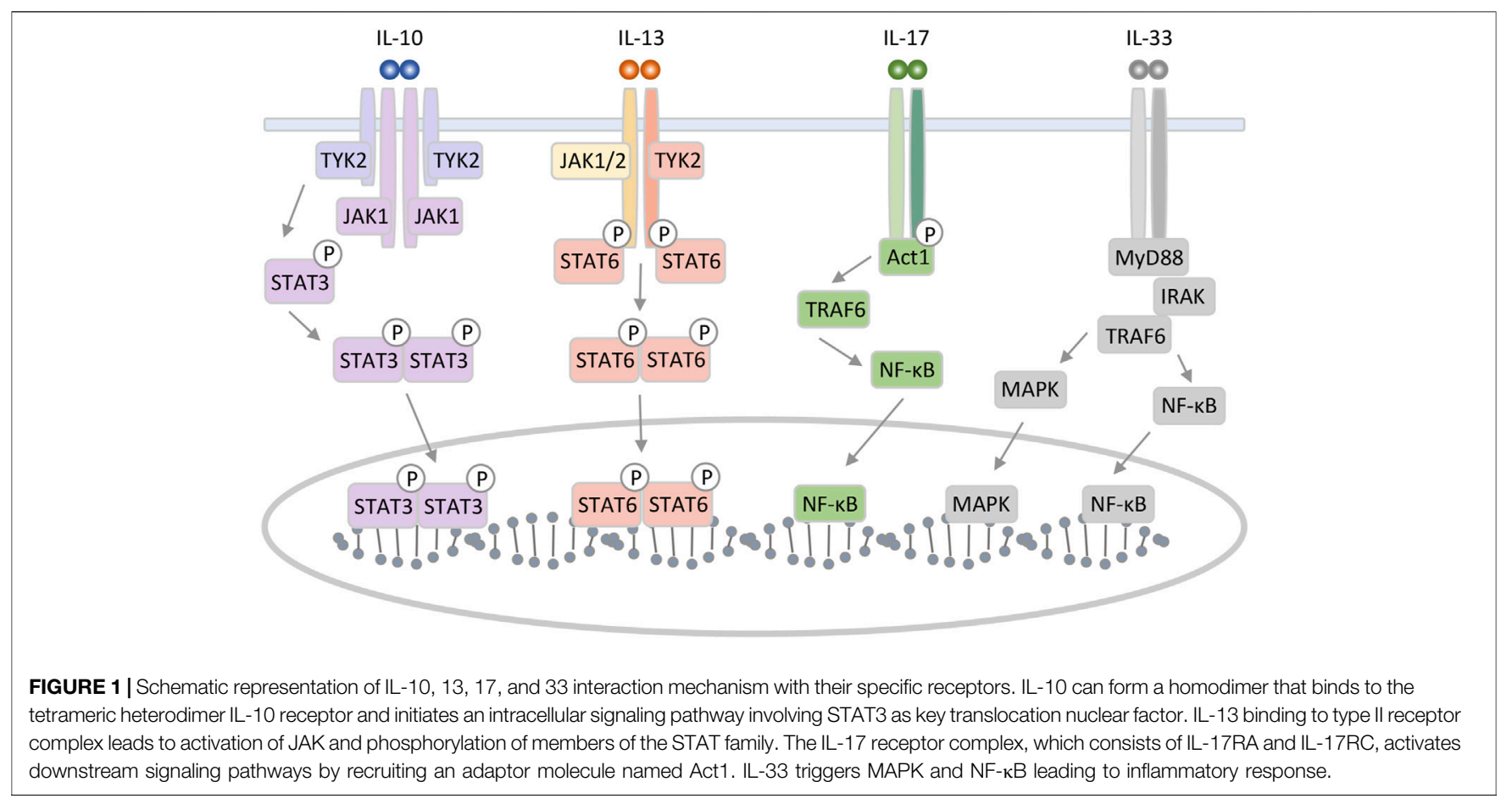

induced by bile duct ligation and carbon tetrachloride $\left(\mathrm{CCl}_{4}\right)$ (McHedlidze et al., 2013).

Hepatocytes produce IL-10 which downregulates proinflammatory responses and has a potential modulatory effect on liver fibrosis (Sziksz et al., 2020). IL-10 gene therapy attenuated hepatic fibrosis and prevented cell apoptosis in a thioacetamide-treated liver. IL-10 gene transfer reduced not only mRNA level of liver TGF- $\beta 1$, TNF- $\alpha$, collagen $\alpha 1$, and cell adhesion molecule, but also decreased the activation of a-smooth muscle actin ( $\alpha$-SMA) and cyclooxygenase-2 (Hung et al., 2005). Other studies have shown that the modification with the IL-10 gene on the buffalo rat liver cells, a rat hepatocytes line, decreased a marked ability to stimulate the primary HSCs proliferation and their expression of $\alpha$-SMA and procollagen type I, and an accelerated apoptosis of the HSCs was induced (Chen et al., 2012). These results suggest that IL-10 gene therapy might be an effective therapeutic reagent for liver fibrosis.

\section{Interleukins in HSCs}

HSCs play a pivotal role in the initiation, perpetuation, and resolution of liver fibrosis. In response to liver injury, quiescent HSCs trans-differentiate into myofibroblasts, and activated HSCs secrete pro-fibrogenic cytokines, growth factors, and ECM molecules (Higashi et al., 2017). Action of HSCs is also regulated by several soluble factors such as TGF $\beta$, platelet-derived growth factor (PDGF), IL-1 $\beta$, and interleukins. These soluble factors are derived from hepatocytes, macrophages, and other immune cells. In the case of interleukins, IL-17, IL-13, and IL-33 promote hepatic fibrogenesis through activation of hepatic stellate cells. In contrast, IL-10 and IL-22 protect from development of fibrosis by suppressing pro-fibrogenic function of HSCs (Hammerich and Tacke, 2014).
Many studies demonstrated that IL-13 is the pre-dominant profibrotic Th2 cytokine in Schistosomiasis infection which leads to granuloma formation and subsequent fibrosis development in the liver. Also, they show that blockade of IL-13 prevented liver fibrogenesis (Chiaramonte et al., 1999; Fallon et al., 2000; Chiaramonte et al., 2001). In the liver, IL-13 directly induces expression of collagen I and other critical fibrosis-associated genes such as a-SMA and connective tissue growth factor (CTGF) in HSCs (Liu et al., 2012). In HSCs, IL-13 induced CTGF by activating TGF- $\beta$-independent activin receptor-like kinase/Smad signaling via the Erkmitogen-activated protein kinase (MAPK) pathway (Liu et al., 2011). A different study by Sui et al. showed that IL-13 stimulated proliferation of HSCs and secretion of TGF- $\beta$ and PDGF by activation protein kinase $\mathrm{C}$ in LX-2, a cell line of human HSCs (Sui et al., 2018).

Numerous studies show that levels of IL-17 and its receptor increased in response to liver injury. Specially, the proinflammatory signaling of IL-17 has been widely studied in HSCs and Kupffer cells (Meng et al., 2012; Tan et al., 2013). Meng et al. demonstrated that IL-17 induced production of collagen type 1 in HSCs through activation of STAT3 signaling pathway. In addition, the author has demonstrated that the activation of fibrin in IL-17-induced HSCs required STAT3 by showing failure to induce collagen-a1 expression in STAT3-deficient HSCs (Meng et al., 2012). A different study showed that pharmacologic inhibition of IL-17-induced ERK1/2 or p38 significantly attenuated HSCs activation and collagen expression (Tan et al., 2013). In vivo experiments demonstrated that blocking IL-17 with anti-IL-17A mAb significantly improved liver function and decreased hepatocellular necrosis, pro-inflammatory cytokines, 
neutrophils and macrophages influx in bile duct ligation-induced liver fibrosis mice (Zhang et al., 2016).

Previous studies have shown that soluble IL-33 increases the secretion of Th2 cytokines such as IL-6, IL-4 and IL-13, which promote HSCs proliferation, TGF- $\beta$ synthesis and fibrogenesis (Wynn, 2004; Schmitz et al., 2005). Meanwhile, another study showed that activated HSCs with recombinant IL-33 released IL6 , TGF- $\beta, \alpha-S M A$, and collagen via MAPK pathways mediated by ERK, c-Jun N-terminal kinase, and p38 protein kinases. Furthermore, the activation of HSCs, liver injury, and inflammatory cell infiltration were reduced in ST2 (IL-33 receptor)-deficient mice (Tan et al., 2017). Marvie et al. identified that IL-33 is upregulated in human and murine fibrosis, and is expressed by HSCs. Activated HSCs was a source of IL-33 that is strongly associated with fibrosis in chronic liver injury (Marvie et al., 2009). These results suggest that IL-33 can play an important role in the cross-talk between HSCs and Th2 cells in liver fibrosis.

The profibrogenic function of HSCs is suppresses by IL-10 which is one of the major anti-inflammatory cytokines. The increase of $\alpha$-SMA and NF- $\mathrm{KB}$ in HSCs was attenuated by ectogenic IL-10 in CCl4-induced liver fibrosis (Zhang et al., 2006). Recently, studies demonstrated that IL-10 induced senescence of activated HSCs via STAT3-p53 pathway to attenuate liver fibrosis (Huang et al., 2020). The therapeutic effects of IL-10 were shown in experiments in vivo in which IL-10 gene therapy reduced the expression of fibrosis-related genes including TGF- $\beta$, TNF- $\alpha$, and collagen $\alpha 1$, and also decreased the activation of $\alpha$-SMA in thioacetamide-induced liver fibrosis (Hung et al., 2005).

\section{Interleukins in Hepatic Macrophages}

Hepatic macrophages consist of Kupffer cells, the largest population of liver resident macrophages, and inflammatory monocytes-derived macrophages (MoMFs) recruited from blood circulation and originated from bone marrow, spleen, and peritoneum. Recruited MoMFs undergo a process of differentiation into M1 (classically activated) or M2 (alternatively activated) species depending on the microenvironment (Van der Heide et al., 2019). Generally, following liver injury by many different factors, the resident Kupffer cells are activated and produce cytokines and chemokines to recruit monocytes and neutrophils. The recruited Ly6C + MoMFs release pro-fibrotic molecules like TGF- $\beta$, TNF- $\alpha$, IL- $1 \beta$, PDGF and CC chemokine ligand 2, and these cytokines activate HSCs and promote liver fibrosis (Dong et al., 2019; Van der Heide et al., 2019). Recently, novel methods on targeting liver macrophages in fibrosis focus on regulating the activation of Kupffer cells, MoMFs recruitment, and macrophage polarization and differentiation (Tacke, 2017).

Kupffer cells not only express the receptor of IL-17, but also produce IL-17 which is mainly produced by Th17 cells (Ge and You, 2008). Meng et al. demonstrated that Kupffer cells, stimulated by IL-17, expressed inflammatory cytokines IL-6, IL- $1 \beta$, TNF- $\alpha$, and TGF- $\beta 1$, which in turn, induced transdifferentiation of HSCs into fibrogenic myofibroblasts, and further facilitated differentiation of IL-17 producing cells
(Meng et al., 2012). A very recent study showed that IL-17 is a cytokine that promotes tumors, critically controlling the inflammatory response in macrophages and the cholesterol synthesis in steatotic hepatocytes in the experimental model of alcohol-induced hepatocellular carcinoma. Therefore, the authors suggested the possibility of IL-17 as a potential treatment target for patients with alcohol-induced hepatocellular carcinoma as well as fibrosis (Ma et al., 2020).

Kupffer cells provide an anti-inflammatory microenvironment by secreting the anti-inflammatory cytokines IL-10 (Heymann et al., 2015; Van der Heide et al., 2019). Antigen presentation to Kupffer cells induces the arrest of CD4 T cells and the secretion of IL-10, an immunosuppressive cytokine, which results in promoting the immune tolerance (Van der Heide et al., 2019). Alternatively, activated M2 macrophages inhibit inflammatory reactions and secrete IL-10, IL-4/IL-13, TGF- $\beta$, and vascular endothelial growth factor- $\alpha$ to facilitate tissue repair. In contrast to the M2, M1 is pro-inflammatory, microbicidal, and tumoricidal. M1 also releases numerous inflammatory cytokines e.g., TNF- $\alpha$, IL-1, IL-6, IL-12, IL-15, and IL-18 (Roszer, 2015; Wang et al., 2018). IL-10 mRNA was upregulated from both Kupffer cells in vitro and in whole liver after treatment with lipopolysaccharide or CCl4. Also, IL-10 inhibited production of superoxide and TNF- $\alpha$ in rat Kupffer cells following lipopolysaccharide treatment. Furthermore, IL$10-/-$ mice showed significantly more severe fibrosis than wild type controls after 70 days of injection with $\mathrm{CCl} 4$. The authors concluded that synthesized IL-10 may modulate Kupffer cells action during the liver inflammation and fibrosis, and influence subsequent progression of fibrosis (Thompson et al., 1998).

\section{DISCUSSION}

In this review, we have shown the main roles of interleukins in a complex and active cross-talk between hepatic cells responses during liver injury, and their potential as therapeutic targets. Fibrosis is characterized by abnormal ECM derived from HSCs, but it is a dynamic process driven by cytokine-mediated signaling pathways, starting with hepatocytes which are directly involved in the initiation and progression of fibrosis, continuing with macrophages that promote inflammation and present antigens to $\mathrm{CD} 4 \mathrm{~T}$ cells which then adjust the immune responses. Interleukins are an immunomodulatory cytokine that is deeply involved from the initiation to the resolution of fibrosis. Recently, the development of a targeted therapy related to liver fibrosis using monoclonal antibodies against interleukins has received considerable interest (Table 1). This antibody treatment targeting interleukins has shown potential as a therapeutic agent in various liver diseases through animal experiments. Treatment with monoclonal antibody neutralizing IL-1 $\beta$ and IL-1 receptor antagonist have been tested in clinical trials. While the anticytokine therapies can prevent the progression of hepatic fibrogenesis in the early stages of liver injury, they are not a cure for advanced liver fibrosis. Therefore, treatment at the liver fibrosis stage that prevents the progression of the disease, and that leads to resolution is very important. In addition, hepatic fibrosis 
TABLE 1 | Strategies targeting interleukins for liver disease.

\begin{tabular}{|c|c|c|c|c|}
\hline Agent & Condition or disease & $\begin{array}{l}\text { Objective or effector } \\
\text { function }\end{array}$ & Trial number & References \\
\hline \multicolumn{5}{|c|}{ Antibodies } \\
\hline $\begin{array}{l}\text { Monoclonal antibody } \\
\text { neutralizing } \mathrm{IL}-1 \beta \\
\text { (Canakinumab) }\end{array}$ & Alcoholic hepatitis & $\begin{array}{l}\text { Explore the potential benefits of the } \mathrm{IL}-1 \beta \text { antibody } \\
\text { (Canakinumab) in the treatment of alcoholic hepatitis }\end{array}$ & NCT03775109 & Dinarello et al. (2012) \\
\hline $\begin{array}{l}\text { IL-1 receptor antagonist } \\
\text { (Anakinra) }\end{array}$ & Alcoholic hepatitis & $\begin{array}{l}\text { Determine the clinical efficacy and safety of IL-1 receptor } \\
\text { antagonist (Anakinra, plus zinc) in participants with } \\
\text { clinically severe alcoholic hepatitis }\end{array}$ & NCT04072822 & $\begin{array}{l}\text { Meier et al. (2019), } \\
\text { Dasarathy et al. (2020) }\end{array}$ \\
\hline $\begin{array}{l}\text { Polymorphism of IL-1 } \beta \\
\text { and TNF- } \alpha\end{array}$ & $\begin{array}{l}\text { Hepatitis B, HCC, } \\
\text { Chronic liver disease }\end{array}$ & $\begin{array}{l}\text { Find the effects of polymorphism of IL- } 1 \beta \text { and TNF- } \alpha \text { and } \\
\text { their interaction on susceptibility and severity of HBV- } \\
\text { related HCC }\end{array}$ & NCT00629486 & Dondeti et al. (2016) \\
\hline $\begin{array}{l}\text { Anti-IL-20 or IL-20R1 } \\
\text { monoclonal antibody }\end{array}$ & $\begin{array}{l}\text { Short-term and long-term } \\
\text { CCl4 -induced liver injury }\end{array}$ & $\begin{array}{l}\text { Attenuated hepatocyte damage, inhibited TGF- } \beta 1 \\
\text { production, liver fibrosis, HSC activation, and ECM } \\
\text { accumulation }\end{array}$ & - & Chiu et al. (2014) \\
\hline $\begin{array}{l}\text { Monoclonal antibody } \\
\text { neutralizing IL-11 and } \\
\text { anti-IL11RA }\end{array}$ & $\begin{array}{l}\text { Non-alcoholic } \\
\text { steatohepatitis }\end{array}$ & $\begin{array}{l}\text { Prevents liver inflammation and steatosis, reverses } \\
\text { severe hepatocyte damage, reduces hepatic immune } \\
\text { cells and TGF } \beta 1 \text { levels } \\
\quad \text { Fusion protein }\end{array}$ & - & Widjaja et al. (2019) \\
\hline $\begin{array}{l}\text { Nanocomplexes with } \\
\text { IL-22 gene }\end{array}$ & $\begin{array}{l}\text { Acetaminophen-induced } \\
\text { liver injury, Concanavalin } \\
\text { A-induced hepatitis. NAFLD }\end{array}$ & $\begin{array}{l}\text { Activated STAT3/Erk signaling, inhibition of reactive } \\
\text { oxygen species generation, ameliorate acetaminophen- } \\
\text { induced liver injury }\end{array}$ & - & $\begin{array}{l}\text { Chen et al. (2017), Chen } \\
\text { et al. (2018), Zai et al. (2019) }\end{array}$ \\
\hline $\begin{array}{l}\text { Fusion protein of IL-6 and } \\
\text { the soluble IL- } 6 \text { receptor }\end{array}$ & $\begin{array}{l}\text { D-galactosamine induced } \\
\text { acute liver injury }\end{array}$ & $\begin{array}{l}\text { Reversed the state of hepatotoxicity, stimulated liver } \\
\text { regeneration }\end{array}$ & - & Galun et al. (2000) \\
\hline $\begin{array}{l}\text { Fusion protein of } \mathrm{IL}-28 \mathrm{~B} \\
\text { and human serum albumin }\end{array}$ & $\begin{array}{l}\text { Cell culture-derived } \\
\text { hepatitis } \mathrm{C} \text { virus }\end{array}$ & Inhibited hepatitis C virus infection & - & Fayad et al. (2013) \\
\hline $\begin{array}{l}\text { Fusion protein of IL-13 } \\
\text { cytotoxin }\end{array}$ & Nonalcoholic steatohepatitis & $\begin{array}{l}\text { Decline in fibrosis and liver enzymes without organ } \\
\text { toxicity, ameliorates pathological features of NASH }\end{array}$ & - & Shimamura et al. (2008) \\
\hline
\end{tabular}

CCI4, carbon tetrachloride; ECM, extracellular matrix; HBV, hepatitis B virus; HCC, hepatocellular carcinoma; HSC, hepatic stellate cells; IL, interleukin; NAFLD, nonalcoholic fatty liver disease; STAT3/Erk, signal transducer and activator of transcription 3/extracellular signal regulated kinase; TGF, tumor growth factor; TNF, tumor necrosis factor.

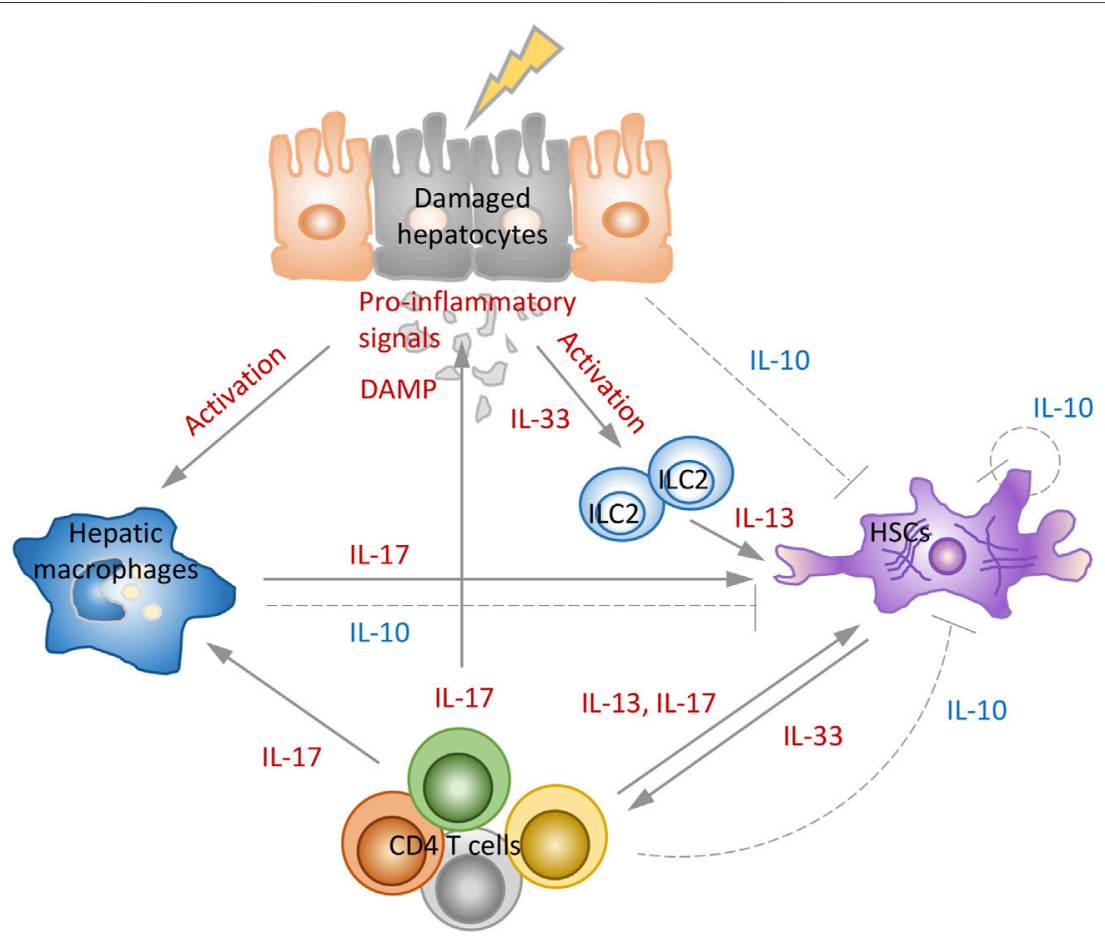

FIGURE 2 | Role of interleukins in development and resolution of liver fibrosis. The combination of signals from inflammatory environment, hepatocytes death, activated macrophages and CD4 T cells stimulates HSCs to proliferate and synthesize collagen and induce fibrosis. IL-33 induces the production of IL-13, and IL-13 and IL-17 directly mediate the activation of HSCs. In the model of fibrosis resolution, hepatocytes, macrophages, HSCs, and CD4 T cells activate the negative feedback loops that reduce immune-mediated fibrosis by secreting IL-10 that prevent activation of HSCs and production of collagen. 
TABLE 2 | Roles of IL-10, 13, 17, and 33 in fibrotic disease.

\begin{tabular}{|c|c|c|c|c|c|c|}
\hline Interleukin & Producing cell & Receptor & Liver & Lung & Heart & Intestine \\
\hline IL-10 & $\begin{array}{l}\text { Basophils, B cells, } \\
\text { dendritic cells, } \\
\text { eosinophils, neutrophils, } \\
\text { macrophages Mast cells, } \\
\text { Th2 cells }\end{array}$ & $\begin{array}{l}\text { IL-10R1(a), } \\
\text { IL-10R2 (b) }\end{array}$ & $\begin{array}{l}\text { IL-10 inhibited HSCs } \\
\text { activation Louis et al. } \\
\text { (1998) IL-gene therapy } \\
\text { reduced the expression } \\
\text { of profibrotic genes } \\
\text { Hung et al. (2005) IL-10 } \\
\text { KO mice showed more } \\
\text { severe liver fibrosis } \\
\text { Thompson et al. (1998) }\end{array}$ & $\begin{array}{l}\text { IL-10 KO mice increased } \\
\text { inflammation after } \\
\text { intratracheal instillation of } \\
\text { silica Huaux et al. (1998) } \\
\text { genetic delivery of IL-10 } \\
\text { attenuated the TGF- } \beta \\
\text { production Nakagome } \\
\text { et al. (2006) }\end{array}$ & $\begin{array}{l}\text { The lack of IL-10 resulted } \\
\text { more severe myocardial } \\
\text { fibrosis Verma et al. } \\
\text { (2012) the administration } \\
\text { of rlL-10 improved } \\
\text { cardiac remodeling } \\
\text { Krishnamurthy et al. } \\
\text { (2009) IL-10 treatment } \\
\text { decreased the myocardial } \\
\text { inflammation in mice with } \\
\text { autoimmune myocarditis } \\
\text { Zimmermann et al. (2012) }\end{array}$ & $\begin{array}{l}\text { Loss of function mutations } \\
\text { in the gene of IL-10 caused } \\
\text { early onset of IBD Kotlarz } \\
\text { et al. (2012) IL-10 } \\
\text { supplementation did not } \\
\text { result clinical improvements } \\
\text { in CD patients Marlow et al. } \\
\text { (2013) }\end{array}$ \\
\hline IL-13 & $\begin{array}{l}\text { Basophils, B cells, } \\
\text { endothelial cells, } \\
\text { eosinophils, epithelial } \\
\text { cells, fibroblasts, mast } \\
\text { cells, macrophages, } \\
\text { monocytes, smooth } \\
\text { muscle cells, Th2 cells }\end{array}$ & $\begin{array}{l}\text { IL-4Ra, } \\
\text { IL13Ra1 }\end{array}$ & $\begin{array}{l}\text { Blockade of IL-13 } \\
\text { prevented liver } \\
\text { fibrogenesis } \\
\text { Chiaramonte et al. } \\
\text { (2001) IL-13 induced } \\
\text { production of collagen, } \\
\text { a-SMA Chiaramonte } \\
\text { et al. (1999) }\end{array}$ & $\begin{array}{l}\text { IL-13-/- and IL-4/13-/- } \\
\text { mice were protected from } \\
\text { lung fibrosis development } \\
\text { in response to FITC } \\
\text { inoculation Kolodsick et al. } \\
\text { (2004) IL-13 and IL-4 are } \\
\text { elevated in the bronchial } \\
\text { alveolar lavage fluid of IPF } \\
\text { patients Park et al. (2009) }\end{array}$ & $\begin{array}{l}\text { ॥13Ra1-deficient mice } \\
\text { develop severe } \\
\text { myocardial dysfunction } \\
\text { Amit et al. (2017) } \\
\text { deficiency of IL-13 leads } \\
\text { to increased leukocyte } \\
\text { infiltration and reduced } \\
\text { M2-like differentiation of } \\
\text { the monocytes in the } \\
\text { myocardium Hofmann } \\
\text { et al. (2014) }\end{array}$ & $\begin{array}{l}\text { IL-13 production by type } 2 \\
\text { NKT cells demonstrated to } \\
\text { be critical for colitis } \\
\text { development Heller et al. } \\
\text { (2002) IL-13 is not } \\
\text { increased in fibrotic CD } \\
\text { muscle layer Vainer et al. } \\
\text { (2000) }\end{array}$ \\
\hline IL-17 & $\begin{array}{l}\text { B cells, dendritic cells, } \\
\text { macrophages, Th17 cells }\end{array}$ & $\begin{array}{l}\text { IL-17RA, } \\
\text { IL-17RC }\end{array}$ & $\begin{array}{l}\text { The increased level of } \\
\text { IL-17 activated HSCs } \\
\text { and induced collagen } \\
\text { production Meng et al. } \\
\text { (2012) elevated levels of } \\
\text { IL-17 were also found in } \\
\text { the fibrotic livers of } \\
\text { patients with hepatitis B } \\
\text { virus and cirrhosis } \\
\text { related liver damage Du } \\
\text { et al. (2013) }\end{array}$ & $\begin{array}{l}\text { Anti-IL-17A neutralizing } \\
\text { antibody attenuated } \\
\text { pulmonary fibrosis and } \\
\text { ECM deposition Chen et al. } \\
\text { (2014) in humans, elevated } \\
\text { levels of IL-17 and IL-1 } \beta \\
\text { were seen in the BAL fluid } \\
\text { of patients with IPE Wilson } \\
\text { et al. (2010) }\end{array}$ & $\begin{array}{l}\text { IL-17 directly induced VA } \\
\text { in vivo and in vitro in a } \\
\text { dose-dependent manner } \\
\text { Chang et al. (2018) IL-17 } \\
\text { induced cardiac fibrosis } \\
\text { both in vitro and in vivo via } \\
\text { PKC } \beta / \text { Erk1/2/NF-kB } \\
\text { signaling pathway Liu } \\
\text { et al. (2012) }\end{array}$ & $\begin{array}{l}\text { IL-17 induced HSP47 as } \\
\text { well as type I collagen in } \\
\text { human intestinal } \\
\text { myofibroblasts Honzawa } \\
\text { et al. (2014) IL-17 } \\
\text { contributed significantly for } \\
\text { stricture development in CD } \\
\text { Yagi et al. (2007) level of } \\
\text { fecal IL-17 was elevated in } \\
\text { patients with active CD } \\
\text { Biancheri et al. (2013) }\end{array}$ \\
\hline IL-33 & $\begin{array}{l}\text { Basophils, B cells, } \\
\text { CD8+T cells, dendritic } \\
\text { cells, eosinophils, ILC2s, } \\
\text { macrophages, mast cells, } \\
\text { natural killer cells, Th2 } \\
\text { cells, Tregs cells }\end{array}$ & $\begin{array}{l}\text { ST2, } \\
\text { IL1RAcP }\end{array}$ & $\begin{array}{l}\text { IL-33-/- mice showed } \\
\text { decrease in collagen } \\
\text { deposition and ECM- } \\
\text { related gene expression } \\
\text { McHedlidze et al. (2013) } \\
\text { production of IL-13 in } \\
\text { Th2 cells Marvie et al. } \\
\text { (2009) IL-33 } \\
\text { exacerbated liver } \\
\text { fibrosis in mice Gao } \\
\text { et al. (2016) }\end{array}$ & $\begin{array}{l}\text { Level of IL-33 was elevated } \\
\text { in the bronchoalveolar } \\
\text { lavage fluids of patients } \\
\text { with IPF Lee et al. (2017) } \\
\text { treatment with anti-IL-33 } \\
\text { antibody markedly } \\
\text { reduced airway } \\
\text { inflammation and lung } \\
\text { fibrosis Luzina et al. (2013) }\end{array}$ & $\begin{array}{l}\text { Recombinant IL-33 } \\
\text { reduced aortic } \\
\text { atherosclerotic plaque } \\
\text { development Miller et al. } \\
\text { (2008) ST2-/- mice } \\
\text { showed more cardiac } \\
\text { fibrosis and impaired } \\
\text { survival Sanada et al. } \\
\text { (2007) expression levels } \\
\text { of IL-33/ST2 in human } \\
\text { myocardial tissue were } \\
\text { associated with cardiac } \\
\text { fibrosis Tseng et al. (2017) }\end{array}$ & $\begin{array}{l}\text { Inhibition of endogenous } \\
\text { ST2-mediated signaling by } \\
\text { treatment with neutralizing } \\
\text { antibody improved DSS- } \\
\text { induced colitis Sedhom } \\
\text { et al. (2013) IL-33 has } \\
\text { extenuating effects in } \\
\text { chronic DSS-induced colitis } \\
\text { Grobeta et al. (2012) }\end{array}$ \\
\hline
\end{tabular}

BAL, bronchoalveolar lavage; CD, crohn's disease; DSS, dextran sulfate sodium; ECM, extracellular matrix; Erk, extracellular signal regulated kinase; HSCs, hepatic stellate cells; HSP, heat shock protein; IBD, inflammatory bowel diseases; IL, interleukin; IPF, idiopathic pulmonary fibrosis; KO, knock-out; NF- kb, nuclear factor-kb; NKT, natural killer T cells; PCK, protein kinase C; r, recombinant; SMA, smooth muscle actin; TGF, tumor growth factor; VA, ventricular arrhythmia.

treatment strategies using various fusion proteins are detailed in Table 1. Targeting IL-22 is particularly promising as an alternative strategy to directly break the cycle of inflammatory cytokine and chemokine signaling, and the fusion protein using the IL-22 gene and nanocomplex is considered a new strategy to improve liver disease (Chen et al., 2017; Chen et al., 2018; Chen et al., 2020).

Damaged hepatocytes activate hepatic macrophages, and release DAMPs and IL-33. ILC2, which is activated by IL-33 released by hepatocytes, secretes IL-13, that can induce the activity of HSCs. Stimulated macrophages modulate antigenpresentation of CD4 $\mathrm{T}$ cells and produce IL-17 together with CD4 T cells, directly affecting the activity of HSCs and collagen production. Additionally, CD4 cells can promote fibrosis by stimulating macrophages and HSCs with IL-17 or IL-13. The quiescent HSCs receiving various pro-inflammatory signals not only transdifferentiate into myofibroblasts to produce collagen, but secrete pro-fibrogenic cytokines such as IL-33 to play pivotal role in fibrosis. On the other hand, during fibrosis resolution, these cells reverse myofibroblast activation with IL-10 and 
regulate the restoration of homeostasis (Figure 2). This suggests that strategies using prevention of pro-inflammatory interleukins or induction of anti-inflammatory interleukins for the treatment of liver fibrosis may be effective.

IL-3, IL-17 and IL-33 induce liver fibrosis through various mechanisms, therefore an approach targeting them as a major participant in the "fibrosis pathway" is expected to be worthwhile. The blockade of IL-13 can be reversed to reduce liver pathology even when fibrosis is already established. IL-17 signals contribute to the pathogenesis of liver damage and IL-17 inhibition can potentially be an effective treatment for liver disease. Furthermore, IL-17 may be a treatment target for alcoholinduced liver damage and hepatocellular carcinoma. An approach aimed at the IL-33/ST2 path could be a potential therapeutic target for human patients suffering from chronic hepatitis and liver fibrosis (Hammerich and Tacke, 2014; Weiskirchen and Tacke, 2016; Zhang et al., 2016; Ma et al., 2020). IL-10 is a typical anti-inflammatory cytokine that shows signals of conservation mechanism in multiple organs. Specially in the fibrous liver, IL-10 has been proven to induce resolution of fibrosis, therefore it is suggested as a potential therapeutic target (Steen et al., 2020). However, the half-life of recombinant IL-10 in vivo is relatively short, and non-targeted administration can cause systemic side effects (Chen et al., 2012). Therefore, increasing numbers of studies have aimed to use IL-10 gene transfer and IL10 gene therapy might be an effective treatment for liver fibrosis.

Fibrosis can occur in almost any organ or tissue, including lung, heart, and intestine, and is associated with a variety of diseases. Although liver fibrosis has been addressed in this review, treatment with specific interleukins can be applied to several tissue fibrosis. Table 2 shows studies using interleukin 10, 13, 17, and 33 in various fibrotic tissues ( $\mathrm{Ng}$ et al., 2018; Wijsenbeek

\section{REFERENCES}

Amit, U., Kain, D., Wagner, A., Sahu, A., Nevo-Caspi, Y., Gonen, N., et al. (2017). New role for interleukin-13 receptor $\alpha 1$ in myocardial homeostasis and heart failure. J. Am. Heart Assoc. 6 (5), e005108. doi:10.1161/JAHA.116.005108

Bansal, R., Nagórniewicz, B., and Prakash, J. (2016). Clinical advancements in the targeted therapies against liver fibrosis. Mediators Inflamm. 2016, 7629724. doi:10.1155/2016/7629724

Barbier, L., Ferhat, M., Salamé, E., Robin, A., Herbelin, A., Gombert, J. M., et al. (2019). Interleukin-1 family cytokines: keystones in liver inflammatory diseases. Front. Immunol. 10, 2014. doi:10.3389/fimmu.2019.02014

Bataller, R., and Brenner, D. A. (2005). Liver fibrosis. J. Clin. Invest. 115, 209-218. doi:10.1172/JCI24282

Biancheri, P., Pender, S. L., Ammoscato, F., Giuffrida, P., Sampietro, G., Ardizzone, S., et al. (2013). The role of interleukin 17 in Crohn's disease-associated intestinal fibrosis. Fibrogenesis Tissue Repair 6, 13. doi:10.1186/1755-1536-6-13

Caraffa, A., Gallenga, C. E., Kritas, S. K., Ronconi, G., Di Emidio, P., and Conti, P. (2019). CAR-T cell therapy causes inflammation by IL-1 which activates inflammatory cytokine mast cells: anti-inflammatory role of IL-37. J. Biol. Regul. Homeost Agents 33, 1981-1985. doi:10.23812/EditorialCaraffa

Chan, A. H., and Schroder, K. (2020). Inflammasome signaling and regulation of interleukin-1 family cytokines. J. Exp. Med. 217, e20190314. doi:10.1084/jem. 20190314

Chang, S. L., Hsiao, Y. W., Tsai, Y. N., Lin, S. F., Liu, S. H., Lin, Y. J., et al. (2018). Interleukin-17 enhances cardiac ventricular remodeling via activating MAPK pathway in ischemic heart failure. J. Mol. Cell. Cardiol. 122, 69-79. doi:10.1016/ j.yjmcc.2018.08.005 et al., 2018; Sziksz et al., 2020). However, there are some practical problems such as the relevant doses of recombinant interleukins, the route of administration, and the costs of production of the cytokine itself, that need to be addressed to move from the experimental stage to the clinical stage. If these hurdles are overcome, a new treatment strategy targeting specific interleukins will be able to deliver expected therapeutic effects not only in the liver, but also in other tissues as well.

\section{AUTHOR CONTRIBUTIONS}

SA and SD developed the outline for this review, SA wrote the first draft with the assistance of AP, SD edited and approved the final version.

\section{FUNDING}

This study was funded by NIH R01 awards (DK082435 and DK112803) and a VA Merit award (BX002638) from the United States Department of Veterans Affairs Biomedical Laboratory Research and Development Service to DeMorrow.

\section{ACKNOWLEDGMENTS}

This work was completed with support from the Veterans Health Administration and with resources and the use of facilities at the Central Texas Veterans Health Care System, Temple, Texas. The contents do not represent the views of the U.S. Department of Veterans Affairs or the United States Government.

Chen, W., Zai, W., Fan, J., Zhang, X., Zeng, X., Luan, J., et al. (2020). Interleukin-22 drives a metabolic adaptive reprogramming to maintain mitochondrial fitness and treat liver injury. Theranostics 10, 5879-5894. doi:10.7150/thno.43894

Chen, W., Zhang, X., Fan, J., Zai, W., Luan, J., Li, Y., et al. (2017). Tethering interleukin-22 to apolipoprotein A-I ameliorates mice from acetaminopheninduced liver injury. Theranostics 7, 4135-4148. doi:10.7150/thno.20955

Chen, W., Luan, J., Wei, G., Zhang, X., Fan, J., Zai, W., et al. (2018). Vivo hepatocellular expression of interleukin-22 using penetratin-based hybrid nanoparticles as potential anti-hepatitis therapeutics. Biomaterials, 187, 66-80. doi:10.1016/j.biomaterials.2018.09.046

Chen, Y., Li, C., Weng, D., Song, L., Tang, W., Dai, W., et al. (2014). Neutralization of interleukin-17A delays progression of silica-induced lung inflammation and fibrosis in C57BL/6 mice. Toxicol. Appl. Pharmacol. 275, 62-72. doi:10.1016/j. taap.2013.11.012

Chen, Y. X., Huang, Y. H., Zheng, W. D., Chen, Z. X., Zhang, L. J., and Wang, X. Z. (2012). Interleukin-10 gene modification attenuates hepatocyte activation of rat hepatic stellate cells in vitro. Mol. Med. Rep. 7, 371-378. doi:10.3892/mmr.2012.1228

Chiaramonte, M. G., Cheever, A. W., Malley, J. D., Donaldson, D. D., and Wynn, T. A. (2001). Studies of murine schistosomiasis reveal interleukin-13 blockade as a treatment for established and progressive liver fibrosis. Hepatology 34, 273-282. doi:10.1053/jhep.2001.26376

Chiaramonte, M. G., Donaldson, D. D., Cheever, A. W., and Wynn, T. A. (1999). An IL-13 inhibitor blocks the development of hepatic fibrosis during a T-helper type 2-dominated inflammatory response. J. Clin. Invest. 104, 777-785. doi:10. 1172/JCI7325

Chiu, Y. S., Wei, C. C., Lin, Y. J., Hsu, Y. H., and Chang, M. S. (2014). IL-20 and IL20R1 antibodies protect against liver fibrosis. Hepatology 60, 1003-1014. doi:10. 1002/hep.27189 
Crispe, I. N. (2016). Hepatocytes as immunological agents. J. Immunol. 196, 17-21. doi:10.4049/jimmunol.1501668

Dasarathy, S., Mitchell, M. C., Barton, B., Mcclain, C. J., Szabo, G., Nagy, L. E., et al. (2020). Design and rationale of a multicenter defeat alcoholic steatohepatitis trial: (DASH) randomized clinical trial to treat alcohol-associated hepatitis. Contemp. Clin. Trials 96, 106094. doi:10.1016/j.cct.2020.106094

De Vries, J. E. (1998). The role of IL-13 and its receptor in allergy and inflammatory responses. J. Allergy Clin. Immunol. 102, 165-169. doi:10.1016/s0091-6749(98) 70080-6

Dinarello, C. A., Simon, A., and Van Der Meer, J. W. (2012). Treating inflammation by blocking interleukin-1 in a broad spectrum of diseases. Nat. Rev. Drug Discov. 11, 633-652. doi:10.1038/nrd3800

Dondeti, M. F., El-Maadawy, E. A., and Talaat, R. M. (2016). Hepatitis-related hepatocellular carcinoma: insights into cytokine gene polymorphisms. World J. Gastroenterol. 22, 6800-6816. doi:10.3748/wjg.v22.i30.6800

Dong, X., Liu, J., Xu, Y., and Cao, H. (2019). Role of macrophages in experimental liver injury and repair in mice. Exp. Ther. Med. 17, 3835-3847. doi:10.3892/etm. 2019.7450

Du, W. J., Zhen, J. H., Zeng, Z. Q., Zheng, Z. M., Xu, Y., Qin, L. Y., et al. (2013). Expression of interleukin-17 associated with disease progression and liver fibrosis with hepatitis B virus infection: IL-17 in HBV infection. Diagn. Pathol. 8, 40. doi:10.1186/1746-1596-8-40

Fallon, P. G., Richardson, E. J., Mckenzie, G. J., and Mckenzie, A. N. (2000). Schistosome infection of transgenic mice defines distinct and contrasting pathogenic roles for IL-4 and IL-13: IL-13 is a profibrotic agent. J. Immunol. 164, 2585-2591. doi:10.4049/jimmunol.164.5.2585

Fayad, H. J., Lamare, F., Le Rest, C. C., Bettinardi, V., and Visvikis, D. (2013). Generation of 4-dimensional CT images based on 4-dimensional PET-derived motion fields. J. Nucl. Med. 54, 631-638. doi:10.2967/jnumed.112.110809

Gallenga, C. E., Pandolfi, F., Caraffa, A., Kritas, S. K., Ronconi, G., Toniato, E., et al. (2019). Interleukin-1 family cytokines and mast cells: activation and inhibition. J. Biol. Regul. Homeost Agents 33, 1-6.

Galun, E., Zeira, E., Pappo, O., Peters, M., and Rose-John, S. (2000). Liver regeneration induced by a designer human IL-6/sIL-6R fusion protein reverses severe hepatocellular injury. FASEB J. 14, 1979-1987. doi:10.1096/fj. 99-0913com

Gao, Y., Liu, Y., Yang, M., Guo, X., Zhang, M., Li, H., et al. (2016). IL-33 treatment attenuated diet-induced hepatic steatosis but aggravated hepatic fibrosis. Oncotarget 7, 33649-33661. doi:10.18632/oncotarget.9259

Ge, D., and You, Z. (2008). Expression of interleukin-17RC protein in normal human tissues. Int. Arch. Med. 1, 19. doi:10.1186/1755-7682-1-19

Gro $\beta$, P., Doser, K., Falk, W., Obermeier, F., and Hofmann, C. (2012). IL-33 attenuates development and perpetuation of chronic intestinal inflammation. Inflamm. Bowel Dis. 18, 1900-1909. doi:10.1002/ibd.22900

Grünig, G., Warnock, M., Wakil, A. E., Venkayya, R., Brombacher, F., Rennick, D. M., et al. (1998). Requirement for IL-13 independently of IL-4 in experimental asthma. Science 282, 2261-2263. doi:10.1126/science.282.5397.2261

Gugliandolo, A., Caraffa, A. L., Gallenga, C. E., Kritas, S. K., Ronconi, G., Trubiani, O., et al. (2019). Mesenchymal stem cells and IL-37: a powerful combination. J. Biol. Regul. Homeost Agents 33, 1019-1022.

Hammerich, L., and Tacke, F. (2014). Interleukins in chronic liver disease: lessons learned from experimental mouse models. Clin. Exp. Gastroenterol. 7, 297-306. doi:10.2147/CEG.S43737

He, Y., Hwang, S., Ahmed, Y. A., Feng, D., Li, N., Ribeiro, M., et al. (2021). Immunopathobiology and therapeutic targets related to cytokines in liver diseases. Cell. Mol. Immunol. 18, 18-37. doi:10.1038/s41423-020-00580-w

Heller, F., Fuss, I. J., Nieuwenhuis, E. E., Blumberg, R. S., and Strober, W. (2002). Oxazolone colitis, a Th2 colitis model resembling ulcerative colitis, is mediated by IL-13-producing NK-T cells. Immunity 17, 629-638. doi:10.1016/s10747613(02)00453-3

Hershey, G. K. (2003). IL-13 receptors and signaling pathways: an evolving web. J. Allergy Clin. Immunol. 111, 677-691. doi:10.1067/mai.2003.1333

Heymann, F., Peusquens, J., Ludwig-Portugall, I., Kohlhepp, M., Ergen, C., Niemietz, P., et al. (2015). Liver inflammation abrogates immunological tolerance induced by Kupffer cells. Hepatology 62, 279-291. doi:10.1002/hep.27793

Higashi, T., Friedman, S. L., and Hoshida, Y. (2017). Hepatic stellate cells as key target in liver fibrosis. Adv. Drug Deliv. Rev. 121, 27-42. doi:10.1016/j.addr.2017.05.007
Hofmann, U., Knorr, S., Vogel, B., Weirather, J., Frey, A., Ertl, G., et al. (2014). Interleukin-13 deficiency aggravates healing and remodeling in male mice after experimental myocardial infarction. Circ. Heart Fail. 7, 822-830. doi:10.1161/ CIRCHEARTFAILURE. 113.001020

Honzawa, Y., Nakase, H., Shiokawa, M., Yoshino, T., Imaeda, H., Matsuura, M., et al. (2014). Involvement of interleukin-17A-induced expression of heat shock protein 47 in intestinal fibrosis in Crohn's disease. Gut 63, 1902-1912. doi:10. 1136/gutjnl-2013-305632

Huang, Y. H., Chen, M. H., Guo, Q. L., Chen, Z. X., Chen, Q. D., and Wang, X. Z. (2020). Interleukin-10 induces senescence of activated hepatic stellate cells via STAT3-p53 pathway to attenuate liver fibrosis. Cell. Signal. 66, 109445. doi:10. 1016/j.cellsig.2019.109445

Huaux, F., Louahed, J., Hudspith, B., Meredith, C., Delos, M., Renauld, J. C., et al. (1998). Role of interleukin-10 in the lung response to silica in mice. Am. J. Respir. Cell Mol. Biol. 18, 51-59. doi:10.1165/ajrcmb.18.1.2911

Hung, K. S., Lee, T. H., Chou, W. Y., Wu, C. L., Cho, C. L., Lu, C. N., et al. (2005). Interleukin-10 gene therapy reverses thioacetamide-induced liver fibrosis in mice. Biochem. Biophys. Res. Commun. 336, 324-331. doi:10.1016/j.bbrc.2005. 08.085

Kagan, P., Sultan, M., Tachlytski, I., Safran, M., and Ben-Ari, Z. (2017). Both MAPK and STAT3 signal transduction pathways are necessary for IL-6dependent hepatic stellate cells activation. PLoS One 12, e0176173. doi:10. 1371/journal.pone. 0176173

Kolodsick, J. E., Toews, G. B., Jakubzick, C., Hogaboam, C., Moore, T. A., Mckenzie, A., et al. (2004). Protection from fluorescein isothiocyanateinduced fibrosis in IL-13-deficient, but not IL-4-deficient, mice results from impaired collagen synthesis by fibroblasts. J. Immunol. 172, 4068-4076. doi:10. 4049/jimmunol.172.7.4068

Kotlarz, D., Beier, R., Murugan, D., Diestelhorst, J., Jensen, O., Boztug, K., et al. (2012). Loss of interleukin-10 signaling and infantile inflammatory bowel disease: implications for diagnosis and therapy. Gastroenterology 143, 347-355. doi:10.1053/j.gastro.2012.04.045

Krishnamurthy, P., Rajasingh, J., Lambers, E., Qin, G., Losordo, D. W., and Kishore, R. (2009). IL-10 inhibits inflammation and attenuates left ventricular remodeling after myocardial infarction via activation of STAT3 and suppression of HuR. Circ. Res. 104, e9-18. doi:10.1161/CIRCRESAHA.108. 188243

Kubes, P., and Jenne, C. (2018). Immune responses in the liver. Annu. Rev. Immunol. 36, 247-277. doi:10.1146/annurev-immunol-051116-052415

Lee, J. U., Chang, H. S., Lee, H. J., Jung, C. A., Bae, D. J., Song, H. J., et al. (2017). Upregulation of interleukin-33 and thymic stromal lymphopoietin levels in the lungs of idiopathic pulmonary fibrosis. BMC Pulm. Med. 17, 39. doi:10.1186/ s12890-017-0380-z

Li, S., Tan, H. Y., Wang, N., Feng, Y., Wang, X., and Feng, Y. (2019). Recent insights into the role of immune cells in alcoholic liver disease. Front. Immunol. 10, 1328. doi:10.3389/fimmu.2019.01328

Liu, Y., Meyer, C., Müller, A., Herweck, F., Li, Q., Müllenbach, R., et al. (2011). IL13 induces connective tissue growth factor in rat hepatic stellate cells via TGF$\beta$-independent Smad signaling. J. Immunol. 187, 2814-2823. doi:10.4049/ jimmunol.1003260

Liu, Y., Munker, S., Müllenbach, R., and Weng, H. L. (2012). IL-13 signaling in liver fibrogenesis. Front. Immunol. 3, 116. doi:10.3389/fimmu.2012.00116

Lokau, J., Schoeder, V., Haybaeck, J., and Garbers, C. (2019). Jak-stat signaling induced by interleukin- 6 family cytokines in hepatocellular carcinoma. Cancers (Basel) 11, 1704. doi:10.3390/cancers 11111704

Louis, H., Van Laethem, J. L., Wu, W., Quertinmont, E., Degraef, C., Van Den Berg, K., et al. (1998). Interleukin-10 controls neutrophilic infiltration, hepatocyte proliferation, and liver fibrosis induced by carbon tetrachloride in mice. Hepatology 28, 1607-1615. doi:10.1002/hep.510280621

Luckheeram, R. V., Zhou, R., Verma, A. D., and Xia, B. (2012). CD4 ${ }^{+}$T cells: differentiation and functions. Clin. Dev. Immunol. 2012, 925135. doi:10.1155/ 2012/925135

Luzina, I. G., Kopach, P., Lockatell, V., Kang, P. H., Nagarsekar, A., Burke, A. P., et al. (2013). Interleukin-33 potentiates bleomycin-induced lung injury. Am. J. Respir. Cell Mol. Biol. 49, 999-1008. doi:10.1165/rcmb.2013-0093OC

Ma, H. Y., Yamamoto, G., Xu, J., Liu, X., Karin, D., Kim, J. Y., et al. (2020). IL-17 signaling in steatotic hepatocytes and macrophages promotes hepatocellular 
carcinoma in alcohol-related liver disease. J. Hepatol. 72, 946-959. doi:10.1016/ j.jhep.2019.12.016

Mair, M., Zollner, G., Schneller, D., Musteanu, M., Fickert, P., Gumhold, J., et al. (2010). Signal transducer and activator of transcription 3 protects from liver injury and fibrosis in a mouse model of sclerosing cholangitis. Gastroenterology 138, 2499-2508. doi:10.1053/j.gastro.2010.02.049

Marlow, G. J., Van Gent, D., and Ferguson, L. R. (2013). Why interleukin-10 supplementation does not work in Crohn's disease patients. World J. Gastroenterol. 19, 3931-3941. doi:10.3748/wjg.v19.i25.3931

Marvie, P., Lisbonne, M., L'helgoualc'h, A., Rauch, M., Turlin, B., Preisser, L., et al. (2009). Interleukin-33 overexpression is associated with liver fibrosis in mice and humans. J. Cell Mol. Med. 14, 1726-1739. doi:10.1111/j.1582-4934.2009. 00801.x

McCormick, S. M., and Heller, N. M. (2015). Commentary: IL-4 and IL-13 receptors and signaling. Cytokine 75, 38-50. doi:10.1016/j.cyto.2015.05.023

McHedlidze, T., Waldner, M., Zopf, S., Walker, J., Rankin, A. L., Schuchmann, M., et al. (2013). Interleukin-33-dependent innate lymphoid cells mediate hepatic fibrosis. Immunity 39, 357-371. doi:10.1016/j.immuni.2013.07.018

Meier, R. P. H., Meyer, J., Montanari, E., Lacotte, S., Balaphas, A., Muller, Y. D., et al. (2019). Interleukin-1 receptor antagonist modulates liver inflammation and fibrosis in mice in a model-dependent manner. Int. J. Mol. Sci. 20 (6), 1295. doi:10.3390/ijms20061295

Meng, F., Wang, K., Aoyama, T., Grivennikov, S. I., Paik, Y., Scholten, D., et al. (2012). Interleukin-17 signaling in inflammatory, Kupffer cells, and hepatic stellate cells exacerbates liver fibrosis in mice. Gastroenterology 143, 765-776.e3. doi:10.1053/j.gastro.2012.05.049

Miller, A. M., Xu, D., Asquith, D. L., Denby, L., Li, Y., Sattar, N., et al. (2008). IL-33 reduces the development of atherosclerosis. J. Exp. Med. 205, 339-346. doi:10. 1084/jem.20071868

Nakagome, K., Dohi, M., Okunishi, K., Tanaka, R., Miyazaki, J., and Yamamoto, K. (2006). In vivo IL-10 gene delivery attenuates bleomycin induced pulmonary fibrosis by inhibiting the production and activation of TGF-beta in the lung. Thorax 61, 886-894. doi:10.1136/thx.2005.056317

Nanchahal, J., and Hinz, B. (2016). Strategies to overcome the hurdles to treat fibrosis, a major unmet clinical need. Proc. Natl. Acad. Sci. U.S.A. 113, 7291-7293. doi:10.1073/pnas.1607896113

Ng, B., Dong, J., D’agostino, G., Viswanathan, S., Widjaja, A. A., Lim, W. W., et al. (2018). Interleukin-11 is a therapeutic target in idiopathic pulmonary fibrosis. Sci. Transl Med. 11, eaaw1237. doi:10.1126/scitranslmed.aaw1237

Onishi, R. M., and Gaffen, S. L. (2010). Interleukin-17 and its target genes: mechanisms of interleukin-17 function in disease. Immunology 129, 311-321. doi:10.1111/j.1365-2567.2009.03240.x

Park, S. W., Ahn, M. H., Jang, H. K., Jang, A. S., Kim, D. J., Koh, E. S., et al. (2009). Interleukin-13 and its receptors in idiopathic interstitial pneumonia: clinical implications for lung function. J. Korean Med. Sci. 24, 614-620. doi:10.3346/ jkms.2009.24.4.614

Paul, W. E., and Seder, R. A. (1994). Lymphocyte responses and cytokines. Cell 76, 241-251. doi:10.1016/0092-8674(94)90332-8

Pinto, S. M., Subbannayya, Y., Rex, D. A. B., Raju, R., Chatterjee, O., Advani, J., et al. (2018). A network map of IL-33 signaling pathway. J. Cell Commun. Signal. 12, 615-624. doi:10.1007/s12079-018-0464-4

Roszer, T. (2015). Understanding the mysterious M2 macrophage through activation markers and effector mechanisms. Mediators Inflamm. 2015, 816460. doi:10.1155/2015/816460

Sanada, S., Hakuno, D., Higgins, L. J., Schreiter, E. R., Mckenzie, A. N., and Lee, R. T. (2007). IL-33 and ST2 comprise a critical biomechanically induced and cardioprotective signaling system. J. Clin. Invest. 117, 1538-1549. doi:10.1172/ JCI30634

Schmidt-Arras, D., and Rose-John, S. (2016). IL-6 pathway in the liver: from physiopathology to therapy. J. Hepatol. 64, 1403-1415. doi:10.1016/j.jhep.2016. 02.004

Schmitz, J., Owyang, A., Oldham, E., Song, Y., Murphy, E., Mcclanahan, T. K., et al. (2005). IL-33, an interleukin-1-like cytokine that signals via the IL-1 receptorrelated protein ST2 and induces Thelper type 2-associated cytokines. Immunity 23, 479-490. doi:10.1016/j.immuni.2005.09.015

Sedhom, M. A., Pichery, M., Murdoch, J. R., Foligné, B., Ortega, N., Normand, S., et al. (2013). Neutralisation of the interleukin-33/ST2 pathway ameliorates experimental colitis through enhancement of mucosal healing in mice. Gut 62, 1714-1723. doi:10.1136/gutjnl-2011-301785

Shimamura, T., Fujisawa, T., Husain, S. R., Kioi, M., Nakajima, A., and Puri, R. K. (2008). Novel role of IL-13 in fibrosis induced by nonalcoholic steatohepatitis and its amelioration by IL-13R-directed cytotoxin in a rat model. J. Immunol. 181, 4656-4665. doi:10.4049/jimmunol.181.7.4656

Steen, E. H., Wang, X., Balaji, S., Butte, M. J., Bollyky, P. L., and Keswani, S. G. (2020). The role of the anti-inflammatory cytokine interleukin-10 in tissue fibrosis. Adv. Wound Care (New Rochelle) 9, 184-198. doi:10.1089/wound.2019.1032

Sui, G., Cheng, G., Yuan, J., Hou, X., Kong, X., and Niu, H. (2018). Interleukin (IL)13 , prostaglandin E2 (PGE2), and prostacyclin 2 (PGI2) activate hepatic stellate cells via protein kinase C (PKC) pathway in hepatic fibrosis. Med. Sci. Monit. 24, 2134-2141. doi:10.12659/msm.906442

Sziksz, E., Pap, D., Lippai, R., Béres, N. J., Fekete, A., Szabó, A. J., et al. (2020). Fibrosis related inflammatory mediators: role of the IL-10 cytokine family. Mediators Inflamm. 2015, 764641. doi:10.1155/2015/764641

Tacke, F. (2017). Targeting hepatic macrophages to treat liver diseases. J. Hepatol. 66, 1300-1312. doi:10.1016/j.jhep.2017.02.026

Tan, Z., Liu, Q., Jiang, R., Lv, L., Shoto, S. S., Maillet, I., et al. (2017). Interleukin-33 drives hepatic fibrosis through activation of hepatic stellate cells. Cell. Mol. Immunol. 15, 388-398. doi:10.1038/cmi.2016.63

Tan, Z., Qian, X., Jiang, R., Liu, Q., Wang, Y., Chen, C., et al. (2013). IL-17A plays a critical role in the pathogenesis of liver fibrosis through hepatic stellate cell activation. J. Immunol. 191, 1835-1844. doi:10.4049/jimmunol.1203013

Thompson, K., Maltby, J., Fallowfield, J., Mcaulay, M., Millward-Sadler, H., and Sheron, N. (1998). Interleukin-10 expression and function in experimental murine liver inflammation and fibrosis. Hepatology 28, 1597-1606. doi:10. 1002/hep.510280620

Toniato, E., Frydas, I., Robuffo, I., Ronconi, G., Caraffa, A., Kritas, S. K., et al. (2017). Activation and inhibition of adaptive immune response mediated by mast cells. J. Biol. Regul. Homeost Agents 31, 543-548.

Tseng, C. C. S., Huibers, M. M. H., Van Kuik, J., De Weger, R. A., Vink, A., and De Jonge, N. (2018). The interleukin-33/ST2 pathway is expressed in the failing human heart and associated with pro-fibrotic remodeling of the myocardium. J. Cardiovasc. Transl Res. 11, 15-21. doi:10.1007/s12265-017-9775-8

Tu, T., Calabro, S. R., Lee, A., Maczurek, A. E., Budzinska, M. A., Warner, F. J., et al. (2015). Hepatocytes in liver injury: victim, bystander, or accomplice in progressive fibrosis? J. Gastroenterol. Hepatol. 30, 1696-1704. doi:10.1111/ jgh. 13065

Vainer, B., Nielsen, O. H., Hendel, J., Horn, T., and Kirman, I. (2000). Colonic expression and synthesis of interleukin 13 and interleukin 15 in inflammatory bowel disease. Cytokine 12, 1531-1536. doi:10.1006/cyto.2000.0744

Van der Heide, D., Weiskirchen, R., and Bansal, R. (2019). Therapeutic targeting of hepatic macrophages for the treatment of liver diseases. Front. Immunol. 10, 2852. doi:10.3389/fimmu.2019.02852

Varvara, G., Tettamanti, L., Gallenga, C. E., Caraffa, A., D’ovidio, C., Mastrangelo, F., et al. (2018). Stimulated mast cells release inflammatory cytokines: potential suppression and therapeutical aspects. J. Biol. Regul. Homeost Agents 32, 1355-1360.

Verma, R., Balakrishnan, L., Sharma, K., Khan, A. A., Advani, J., Gowda, H., et al. (2016). A network map of Interleukin-10 signaling pathway. J. Cell Commun. Signal. 10, 61-67. doi:10.1007/s12079-015-0302-x

Verma, S. K., Krishnamurthy, P., Barefield, D., Singh, N., Gupta, R., Lambers, E., et al. (2012). Interleukin-10 treatment attenuates pressure overload-induced hypertrophic remodeling and improves heart function via signal transducers and activators of transcription 3-dependent inhibition of nuclear factor- $\mathrm{kB}$. Circulation 126, 418-429. doi:10.1161/CIRCULATIONAHA.112.112185

Wang, L. X., Zhang, S. X., Wu, H. J., Rong, X. L., and Guo, J. (2019). M2b macrophage polarization and its roles in diseases. J. Leukoc. Biol. 106, 345-358. doi:10.1002/JLB.3RU1018-378RR

Weiskirchen, R., and Tacke, F. (2016). Interleukin-33 in the pathogenesis of liver fibrosis: alarming ILC2 and hepatic stellate cells. Cell Mol. Immunol. 14, 143-145. doi:10.1038/cmi.2016.62

Widjaja, A. A., Singh, B. K., Adami, E., Viswanathan, S., Dong, J., D’agostino, G. A., et al. (2019). Inhibiting interleukin 11 signaling reduces hepatocyte death and liver fibrosis, inflammation, and steatosis in mouse models of nonalcoholic steatohepatitis. Gastroenterology 157, 777-792. doi:10.1053/j.gastro.2019.05.002 
Wijsenbeek, M. S., Kool, M., and Cottin, V. (2018). Targeting interleukin-13 in idiopathic pulmonary fibrosis: from promising path to dead end. Eur. Respir. J. 52, 1802111. doi:10.1183/13993003.02111-2018

Wilson, M. S., Madala, S. K., Ramalingam, T. R., Gochuico, B. R., Rosas, I. O., Cheever, A. W., et al. (2010). Bleomycin and IL-1beta-mediated pulmonary fibrosis is IL-17A dependent. J. Exp. Med. 207, 535-552. doi:10.1084/jem.20092121

Wu, Y., Min, J., Ge, C., Shu, J., Tian, D., Yuan, Y., et al. (2020). Interleukin 22 in liver injury, inflammation and cancer. Int. J. Biol. Sci. 16, 2405-2413. doi:10.7150/ijbs.38925

Wynn, T. A. (2004). Fibrotic disease and the T(H)1/T(H)2 paradigm. Nat. Rev. Immunol. 4, 583-594. doi:10.1038/nri1412

Yagi, Y., Andoh, A., Inatomi, O., Tsujikawa, T., and Fujiyama, Y. (2007). Inflammatory responses induced by interleukin-17 family members in human colonic subepithelial myofibroblasts. J. Gastroenterol. 42, 746-753. doi:10.1007/s00535-007-2091-3

Yan, Y. Y., Lin, S., and Zhu, Y. Y. (2018). Damage-associated molecular patterns and liver failure. Zhonghua Gan Zang Bing Za Zhi 24, 636-640. doi:10.3760/ cma.j.issn.1007-3418.2016.08.017

Zai, W., Chen, W., Wu, Z., Jin, X., Fan, J., Zhang, X., et al. (2019). Targeted interleukin-22 gene delivery in the liver by polymetformin and penetratinbased hybrid nanoparticles to treat nonalcoholic fatty liver disease. ACS Appl. Mater. Inter. 11, 4842-4857. doi:10.1021/acsami.8b19717

Zhang, L. J., Zheng, W. D., Shi, M. N., and Wang, X. Z. (2006). Effects of interleukin-10 on activation and apoptosis of hepatic stellate cells in fibrotic rat liver. World J. Gastroenterol. 12, 1918-1923. doi:10.3748/wjg.v12.i12.1918
Zhang, S., Huang, D., Weng, J., Huang, Y., Liu, S., Zhang, Q., et al. (2016). Neutralization of interleukin-17 attenuates cholestatic liver fibrosis in mice. Scand. J. Immunol. 83, 102-108. doi:10.1111/sji.12395

Zhou, Z., Xu, M. J., and Gao, B. (2016). Hepatocytes: a key cell type for innate immunity. Cell Mol. Immunol. 13, 301-315. doi:10.1038/cmi.2015.97

Zhu, J., and Paul, W. E. (2008). CD4 T cells: fates, functions, and faults. Blood 112, 1557-1569. doi:10.1182/blood-2008-05-078154

Zimmermann, O., Homann, J. M., Bangert, A., Müller, A. M., Hristov, G., Goeser, S., et al. (2012). Successful use of mRNA-nucleofection for overexpression of interleukin-10 in murine monocytes/macrophages for anti-inflammatory therapy in a murine model of autoimmune myocarditis. J. Am. Heart Assoc. 1, e003293. doi:10.1161/JAHA.112.003293

Conflict of Interest: The authors declare that the research was conducted in the absence of any commercial or financial relationships that could be construed as a potential conflict of interest.

Copyright (c) 2021 An, Petrescu and DeMorrow. This is an open-access article distributed under the terms of the Creative Commons Attribution License (CC BY). The use, distribution or reproduction in other forums is permitted, provided the original author(s) and the copyright owner(s) are credited and that the original publication in this journal is cited, in accordance with accepted academic practice. No use, distribution or reproduction is permitted which does not comply with these terms. 